\title{
Surgical treatment in critical limb ischaemia
}

\author{
G Roscitano*, A Cotroneo \\ From de Senectute: Age and Health Forum \\ Catanzaro, Italy. 5-7 December 2009
}

\section{Background}

Recommendations of clinical guidelines for the treatment of critical limb ischemia (CLI) are based on randomized controlled trials [1]. Surgery using different grafts (venous or prosthetic) is in competition with percutaneous angioplasty. Progress of endoluminal techniques has brought certain authors to think that angioplasty is now the first treatment of critical limb ischemia [2].

\section{Materials and methods}

The indications of TASC II are: endovascular for type A, endovascular (with qualifications) for type $B$, open surgical (with qualifications) for type $\mathrm{C}$, and open surgical for type D. [3].

Our experience, from 2000 to 2009, is of 377 patients (250 m - 127 f.). We perform distal revascularizations (tibial, peroneal and plantar) with great, small saphen vein and veins of the arm on 407 limbs. Mean age: $72 \mathrm{y}$. (19-25). Our patients had as risk factors: IDDM 66\%, CAD 47\%, CABG 8\%, COPD 70\%, ESRD 20\% and 9,5\% were in dialytic treatment.

\section{Results}

We have a 30 day mortality rate of $2.7 \%$, graft occlusion $9 \%$ and amputation $2.6 \%$. Comparing our results to those of the literature for venous or prosthetic bypasses and distal angioplasties, we remain convinced of the high efficiency, in the long run, of infra-popliteal venous bypass grafts. Meanwhile, recent data on distal angioplasties are promising and in constant progress. [2].

Published: 19 May 2010

Department of Cardiovascular Surgery - Sant'Anna Hospital, Catanzaro, Italy
References

1. Lawall $\mathrm{H}$, et al: Long-term outcomes after medical and interventional therapy of critical limb ischemia. Eur J Intern Med. 2009, 20(6):616-21.

2. De Vos B, et al: Do surgical distal bypasses still play a role in the treatment of critical limb ischemia? Acta Chir Belg. 2009, 109(4):465-76.

3. Lyden SP, Smouse HB: TASC II and the endovascular management of infrainguinal disease. J Endovasc Ther. 2009, 16(2 Suppl 2):I15-18.

doi:10.1186/1471-2318-10-S1-A73

Cite this article as: Roscitano and Cotroneo: Surgical treatment in critical limb ischaemia. BMC Geriatrics 2010 10(Suppl 1):A73.
Submit your next manuscript to BioMed Central and take full advantage of:

- Convenient online submission

- Thorough peer review

- No space constraints or color figure charges

- Immediate publication on acceptance

- Inclusion in PubMed, CAS, Scopus and Google Scholar

- Research which is freely available for redistribution

Submit your manuscript at www.biomedcentral.com/submit
C Biomed Central 